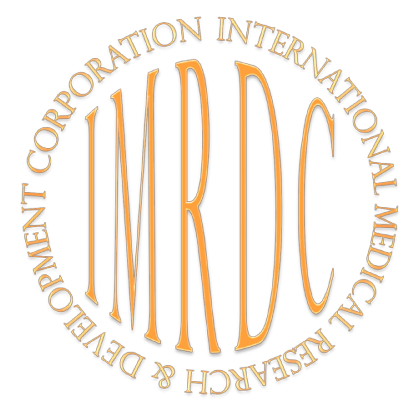

\title{
Chronic Triple Infection with Hepatitis B, C, and D Viruses in the Republic of Sakha (Yakutia)
}

\author{
Lubov I. Petrova, MD, PhD; Snezhana S. Sleptsova, MD, PhD, ScD*; \\ Maksim N. Andreev; Nikolai M. Gogolev, MD, PhD; Anastasia N. Petrova \\ M. K. Ammosov North-Eastern Federal University \\ Yakutsk, the Republic of Sakha (Yakutia), Russia
}

\begin{abstract}
The purpose of this work was to study the features of the clinical course of mixed infections with hepatitis $\mathrm{B}+\mathrm{C}+\mathrm{D}$ viruses in the Republic of Sakha (Yakutia) (RS(Y)).

Materials and Methods: The incidences of these infections were studied in the infectious disease department of the Yakutsk City Clinical Hospital. A total of 74 patients with chronic infection with hepatitis B, C, and D viruses were analyzed. The following markers of HBV (HBsAg, HBeAg, anti-HBcIgG, HBV DNA), HCV (anti-HCV) and HDV (anti-HDV, HDV RNA) were detected.

Results: According to PCR ( $\mathrm{n}=35$ ), HCV-RNA was detected in $29(82.8 \%)$ patients. In $65.8 \%$ of cases, HCV-RNA replication was observed in the absence of HDV-DNA. Mono-replication of HBV (HBV-DNA+, HCV-RNA-) was detected in $17.1 \%$ patients, mono-replication of HCV (HBV-DNA-, HCV-RNA+) in $65.7 \%$ patients and mixed replication of viruses C, D and/or G (HBV-DNA-, HCV-RNA+, HDV-RNA+/HGV-RNA+) in 17.1\% patients. The comparison of biochemical parameters of patients with chronic mixed hepatitis showed that more expressed changes are observed with the mixed replication than with the mono-replicative form of hepatitis.(International Journal of Biomedicine. 2018;8(3):217-219.)
\end{abstract}

Key Words: chronic mixed hepatitis $\bullet$ hepatitis B virus $\bullet$ hepatitis $\mathrm{C}$ virus $\bullet$ hepatitis D virus

\section{Abbreviations}

CVH, chronic viral hepatitis; CHB, chronic hepatitis B; CHC, chronic hepatitis C; HBV, hepatitis B virus; HCV, hepatitis C virus; HDV, hepatitis D virus; HGV, hepatitis G virus.

\section{Introduction}

HCV, HBV, and HDV share parallel routes of transmission; because of this, dual or triple viral infection can occur in a proportion of patients at the same time. In 1991-1995, only $2.6 \%$ of adult patients with acute viral hepatitis had a mixed etiology of the disease, but in recent years, multiple hepatitis

*Corresponding author: Prof. Snezhana S. Sleptsova, MD, $P h D, S c D$. Head of the Department of Infectious Diseases, Phthisiatrics and Dermatovenerology of Medical Institute at M. K. Ammosov NorthEastern Federal University. Yakutsk, the Sakha Republic, Russia. E-mail: sssleptsova@yandex.ru co-infection reached $13.8 \%-16.8 \%$. $^{(1-6)}$ The proportion of patients with multiple hepatitis co-infections depends on the environmental and clinical setting.(7) The Republic of Sakha (Yakutia) $(\mathrm{RS}(\mathrm{Y}))$ is one of the regions of Russia that is unfavorable for the prevalence of viral hepatitis B, C and D, as well as their adverse outcomes - cirrhosis and primary liver cancer. ${ }^{(8)}$ According to the electronic register "Chronic viral hepatitis in Yakutia," 14,791 people are registered and 4.3\% of them have chronic triple infection with hepatitis B, C, and $\mathrm{D}$ viruses.

The purpose of this work was to study the features of the clinical course of mixed infections with hepatitis $\mathrm{B}+\mathrm{C}+\mathrm{D}$ viruses in $\mathrm{RS}(\mathrm{Y})$. 


\section{Materials and Methods}

We studied the data of the incidences of these infections in the infectious disease department of the Yakutsk City Clinical Hospital. The following examinations were performed: physical examination, as well as clinical, biochemical, serological (ELISA) and molecular (PCR) evaluations. The following markers of $\mathrm{HBV}$ (HBsAg, $\mathrm{HBeAg}$, anti-HBcIgG, HBV DNA), HCV (anti-HCV) and HDV (anti-HDV, HDV RNA) were detected.

Statistical analysis was performed using the statistical software «Statistica» (v8.0, StatSoft, USA). Baseline characteristics were summarized as frequencies and percentages for categorical variables and as means and SEMs for continuous variables. Categorical variables were analyzed using the Chi-square test with the Yates' correction. Comparisons between three groups were performed with the oneway ANOVA with Tukey's post-hoc test. A probability value of $P<0.05$ was considered statistically significant.

\section{Results and Discussion}

A total of 74 patients (59.5\% male and $40.5 \%$ female) with chronic triple infection with hepatitis $\mathrm{B}, \mathrm{C}$, and $\mathrm{D}$ viruses were analyzed. Nineteen $(25.7 \%)$ of them were in the cirrhotic stage. The distribution of patients based on degree of activity of $\mathrm{CVH}(\mathrm{n}=55)$ was as follows: chronic viral hepatitis with minimal activity was registered in $18.2 \%$ of patients, with moderate and severe activity in $23.6 \%$ and $58.3 \%$ of patients, respectively.

Most of the patients (68.9\%) were residents of Yakutsk. Chronic mixed hepatitis was registered in patients from 15 districts. The largest number of patients was registered in the central and western zones of RS(Y) (Namsky, Nyurbinsky and Khangalas districts). Chronic mixed hepatitis was observed in indigenous people in $59.4 \%$ of cases, among non-indigenous people in $40.6 \%$. A prevalence of young people under 29(41.9\%) was noted.

During our study of the epidemiological anamnesis, we found that in $36.5 \%$ of patients there was an indication of previously endured acute B hepatitis. A history of parenteral manipulations, including operations, dental manipulations and various other parenteral interventions, was noted in $67.5 \%$ of patients. In $20.3 \%$ of cases, the development of the disease was linked with family contact. In $5.4 \%$ of cases, hepatitis occurred after intravenous drug use. About $6.8 \%$ of patients had association with sexually transmitted diseases, which suggests the possibility of the sexual way of transmission due to absence of other factors of possible infection with hepatitis B. Alcohol abuse was noted in 7(9.4\%) patients, while the proportion of people with chronic hepatitis in the cirrhotic stage was $21 \%$.

Molecular diagnostics was performed on 35 patients. HCV-RNA was detected in $29(82.8 \%)$ patients. In $65.8 \%$ of cases, HCV-RNA replication was observed in the absence of HDV-DNA. Suppression of HBV replication by HCV in acutely or chronically infected patients is well-described phenomenon. In vivo study in chimpanzees showed that acute
HCV superinfection in chronic HBV infection resulted in marked reduction in the titer of serum HBsAg. ${ }^{(9,10)}$ In clinical studies, the inhibition of HBV replication by HCV was also observed. ${ }^{(11,12)}$ The mechanisms accounting for the suppression of HCV on HBV were investigated by Shih et al. ${ }^{(13)}$ Their findings suggest that $\mathrm{HCV}$ may directly interfere with $\mathrm{HBV}$ replication and furthermore identified the $\mathrm{HCV}$ core protein as a repressor of $\mathrm{HBV}$ production.

HBV-DNA was detected in 6(17.1\%) patients, HDVRNA in $4(11.4 \%)$ patients, and HGV-RNA in $1(2.8 \%)$ patient. Chronic hepatitis with severe and moderate activity was diagnosed in all patients. HCV-RNA was not found in 6(17.1\%) patients, and 29(82.9\%) patients had no HBV-DNA replication.

Patients were divided by replicative activity into 3 groups: Group 1 included 6(17.1\%) patients with monoreplication of HBV (HBV-DNA+, HCV-RNA-), Group 2 included 23(65.7\%) patients with mono-replication of HCV (HBV-DNA-, HCV-RNA+), and Group 3 included 6(17.1\%) patients with the observed mixed replication of viruses $\mathrm{C}$, D and/or G (HBV-DNA-, HCV-RNA+, HDV-RNA+/HGVRNA+).

HBsAg was detected in 27(77.1\%) patients, including $83.3 \%, 86.9 \%$ and $33.3 \%$ in Groups 1,2 and 3, respectively. The diagnosis of CHB was confirmed by the detection of antibodies to $\mathrm{HBeAg}$ in $20 \%$ of cases, total antibodies to $\mathrm{HBcAg}$ in $74.3 \%$ of cases and only in one patient (2.8\%) by PCR. Antibodies to HCV were detected in 30(85.7\%) patients by ELISA; in the other $5(14.3 \%)$ patients, diagnosis was confirmed by PCR. CHD was verified in 5(14.3\%) patients by ELISA, and HDVRNA in these cases was detected in $4(80 \%)$ patients.

Depending on the replicative activity of $\mathrm{HBV}$ and $\mathrm{HCV}$, we studied clinical symptoms (Table 1). The main complaint of patients was an asthenic syndrome, manifested by unmotivated weakness and fatigue. The second place complaint was a dyspeptic syndrome with the greatest frequency in patients with mixed replication of hepatitis viruses. Jaundice and splenomegaly was observed mostly in patients with replication of HCV and the mixed replicative form of chronic hepatitis. Hepatomegaly was detected in $73.9 \%, 50.0 \%$ and $33.3 \%$ of patients in Groups 2, 3 and 1, respectively.

Table 1.

Clinical symptoms depending on the replicative activity of $\mathrm{HBV}$ and $\mathrm{HCV}$

\begin{tabular}{|l|c|c|c|c|c|c|}
\hline \multicolumn{1}{|c|}{$\begin{array}{c}\text { Symptoms and } \\
\text { syndromes }\end{array}$} & \multicolumn{2}{|c|}{ Group 1 } & \multicolumn{2}{c|}{ Group 2 } & \multicolumn{2}{c|}{ Group 3 } \\
\cline { 2 - 7 } & $\mathrm{n}$ & $\%$ & $\mathrm{n}$ & $\%$ & $\mathrm{n}$ & $\%$ \\
\hline Asthenic syndrome & 5 & 83.3 & 23 & 100 & 6 & 100 \\
$\begin{array}{l}\text { Dyspeptic } \\
\text { syndrome }\end{array}$ & 3 & 50.0 & 18 & 78.3 & 6 & 100 \\
Hemorrhagic & 1 & 16.7 & 9 & 39.1 & 4 & 66.7 \\
syndrome & 1 & 16.7 & 14 & 60.9 & 3 & 50.0 \\
Pain & - & - & 7 & 30.4 & 3 & 50.0 \\
Jaundice & 2 & 33.3 & 17 & 73.9 & 3 & 50.0 \\
Hepatomegaly & - & - & 5 & 21.7 & 4 & 66.7 \\
Splenomegaly & 1 & 16.7 & 12 & 52.2 & 3 & 50.0 \\
Arthralgia & 1 & 16.7 & 10 & 43.5 & 5 & 83.3 \\
Telangiectasia & \multicolumn{7}{|c|}{} \\
\hline
\end{tabular}


The frequency of extrahepatic manifestations was most often found in patients of Group 3, then in Group 2. In patients of Group 1, we found equal frequencies (16.7\%) of arthralgia and telangiectasia. Aminotransferase activity was the highest in Group $3(4.6 \pm 0.54 \mathrm{mmol} / \mathrm{l})$ and the lowest in Group 1 $(0.72 \pm 0.4 \mathrm{mmol} / \mathrm{l})($ Table 2$)$. An increase in the serum level of bilirubin up to $45.0 \pm 36.2 \mathrm{mmol} / 1$ was also observed in Group 3. The comparison of biochemical parameters of patients with chronic mixed hepatitis showed that more expressed changes are observed with the mixed replication than with the monoreplicative form of hepatitis.

Table 2.

Biochemical markers depending on the replicative activity of $\mathrm{HBV}$ and $\mathrm{HCV}$

\begin{tabular}{|l|c|c|c|c|}
\hline \multicolumn{1}{|c|}{ Variable } & Group 1 & Group 2 & Group 3 & $P$-value \\
\hline ALT, mmol/L & $0.72 \pm 0.4$ & $2.34 \pm 0.4$ & $4.65 \pm 0.54$ & 0.002 \\
\hline $\begin{array}{l}\text { Total bilirubin, } \\
\text { mmol/L }\end{array}$ & $15.6 \pm 5.4$ & $36.6 \pm 32.2$ & $45.0 \pm 36.2$ & $>0.05$ \\
\hline Total protein, g/L & $82.7 \pm 1.7$ & $77.2 \pm 4.3$ & $79.3 \pm 6.2$ & $>0.05$ \\
\hline Albumin, g/L & $46.4 \pm 1.2$ & $46.2 \pm 3.6$ & $40.0 \pm 1.3$ & $>0.05$ \\
\hline Platelets, $10^{9} \mathrm{~g} / \mathrm{L}$ & $240.8 \pm 20.5$ & $247.7 \pm 50.1$ & $237.8 \pm 58.8$ & $>0.05$ \\
\hline PTI, \% & $88.9 \pm 6.9$ & $85.9 \pm 9.3$ & $83.3 \pm 5.9$ & $>0.05$ \\
\hline
\end{tabular}

In conclusion, the level of incidence of CVH in RS(Y) remains on a high level. The features of the mixed hepatitis have revealed that the most significant clinical and biochemical changes are common for mixed replication of viruses $B$ and C. For objective assessment of the situation of viral hepatitis and its outcomes in $\mathrm{RS}(\mathrm{Y})$, we recommend including the registration of mixed hepatitis in the unified electronic "Chronic viral hepatitis in RS(Y)" register, as well as official registration of mixed forms of hepatitis in the Federal Service for Supervision of Consumer Rights Protection and Human Well-Being are recommended.

\section{Competing interests}

The authors declare that they have no competing interests.

\section{References}

1. Chu CJ, Lee SD. Hepatitis B virus/hepatitis C virus coinfection: epidemiology, clinical features, viral interactions and treatment. J Gastroenterol Hepatol. 2008;23(4):512-20. doi: 10.1111/j.1440-1746.2008.05384.x.

2. Pontisso P, Gerotto M, Benvegnù L, Chemello L, Alberti A. Coinfection by hepatitis $\mathrm{B}$ virus and hepatitis $\mathrm{C}$ virus. Antivir Ther. 1998;3(Suppl 3):137-42.

3. Rahmanova AG, Yakovlev AA. Chronic viral hepatitis and HIV infection. SPb.: «VVM»; 2011. [In Russian].

4. Shahil'dyan IV, Yasinsky A. [Epidemiological characteristics of chronic hepatitis B and C in the Russian Federation]. Mir Virusnyh Gepatitov. 2008;(5):11-13. [Article in Russian].

5. Yakovlev AA, Vinogradova EN, Rahmanova AG. Chronic viral hepatitis: clinical and laboratory aspects. SPb.: NIIH SPbGU; 2002.[In Russian].

6. Zakirov IG. [Liver cirrhosis and liver cancer associated with viral hepatitis $\mathrm{B}$ and $\mathrm{C}$ in republic of Tatarstan].Zh Mikrobiol Epidemiol Immunobiol. 2003 Jan-Feb;(1):26-8. [Article in Russian]

7. Gaeta GB, Precone DF, Cozzi-Lepri A, Cicconi P, D’Arminio Monforte A. Multiple viral infections. J Hepatol. 2006;44(1 Suppl):S108-13.

8. Sleptsova SS. Parenteral viral hepatitis and their outcomes in the Republic of Sakha (Yakutia). M., 2017. [In Russian].

9. Brotman B, Prince AM, Huima T, Richardson L, van den Ende MC, Pfeifer U. Interference between non-A, non-B and hepatitis B virus infection in chimpanzees. J Med Virol 1983;11(3):191-205.

10. Bradley DW, Maynard JE, McCaustland KA, Murphy BL, Cook EH, Ebert JW. Non-A, non-B hepatitis in chimpanzees: interference with acute hepatitis A virus and chronic hepatitis B virus infections. J Med Virol 1983;11(3):207-13

11. Sagnelli E, Coppola N, Scolastico C, Filippini P, Santantonio T, Stroffolini T, Piccinino F. Virologic and clinical expressions of reciprocal inhibitory effect of hepatitis $\mathrm{B}, \mathrm{C}$, and delta viruses in patients with chronic hepatitis. Hepatology 2000;32(5):1106-10. 12. Jardi R, Rodriguez F, Buti M, Costa X, Cotrina M, Galimany R, et al. Role of hepatitis B, C, and D viruses in dual and triple infection: influence of viral genotypes and hepatitis B precore and basal core promoter mutations on viral replicative interference. Hepatology 2001;34(2):404-10.

13. Shih CM, Lo SJ, Miyamura T, Chen SY, Lee YH. Suppression of hepatitis B virus expression and replication by hepatitis $\mathrm{C}$ virus core protein in $\mathrm{HuH}-7$ cells. J Virol 1993;67(10):5823-32. 